IDEAS IN ECRLGGY AND EVILUTION 5: 54-56, 2012

doi:10.4033/iee.2012.5.12.c

(C) 2012 The Author. (C) Ideas in Ecology and Evolution 2012

Received 16 June 2012; Accepted 25 September 2012

\title{
Commentary
}

\section{Clarity, confusion, and idea refining in ecology}

\section{Brian M. Starzomski}

Brian M. Starzomski (starzom@uvic.ca), School of Environmental Studies, University of Victoria, Victoria, BC V8W $3 R 4$

The term "resilience" is among the most seductively simple in all of ecology. But is it true? Is the definition strong, or loosely understood and used? And more importantly, is there evidence supporting its utility in applied ecology and management?

The original definition of resilience is: "Resilience determines the persistence of relationships within a system and is a measure of the ability of these systems to absorb changes of state variables, driving variables, and parameters, and still persist" (Holling 1973: 17). This is a remarkably broad definition for a scientifically useful term, though of course it has become well used in the management and policy literature (e.g., Chapin et al. 2009). Elsewhere it has been stated that ecology has what may be considered a terminology problem (e.g., Shrader-Frechette and McCoy 1993, Mikkelson 1997), though others offer a more optimistic view of the multiple meanings of widely used terms (e.g., Hodges 2008, Vellend 2010). Few studies have explicitly sought to experimentally test whether individual systems exhibit resilience in one or another component (see Carpenter et al. 1992 and Rydgren et al 2004 for examples), and as a consequence the term finds little support amongst experimental ecologists. Nevertheless, observational studies that appear to demonstrate changes to, or loss of, system resilience are numerous, and included in a database on the Resilience Alliance's own website (Resilience Alliance and Santa Fe Institute 2012).

The Stockholm Resilience Centre, a primary centre for resilience studies, defines resilience as "[T] he capacity of a system to continually change and adapt yet remain within critical thresholds". This definition is even broader than Holling's (1973) original definition, yet it is very much what the term has most frequently come to mean in the natural resources management literature.
One might argue that the best a scientific paper can hope for is to be considered a legitimate idea about nature, and to stimulate subsequent research to refine its ideas, to provide examples of where else they might apply. In the case of the term 'resilience', it might be argued that its introduction to the ecological literature (by Holling in 1973) started at the top (i.e., in its original form it was meant to be applied to all ecosystems). If we judge the success of an idea's introduction by the number of citations it gets, then surely resilience must be considered very successful (original paper cited 3892 times, other papers listed in Myers-Smith et al. (2012) cited a total of 4240 times as of June $15^{\text {th }}, 2012$ according to Google Scholar ${ }^{1}$ ). Whether or not the term is always used in exact reference to its original definition, resilience has stimulated a huge amount of thought in conservation science and for that reason alone it must be considered to be successful.

Does a term need to be defined exactly to be useful? In its strictest sense the answer must be no, otherwise we would not use models in ecology. 'All models are wrong, some are useful' is a commonly heard idea that partly explains why we develop models that don't explain any specific situation, but rather help to exclude extraneous predictors for a pattern or process in nature.

Logical descriptions of nature using a subset of all possible variables help to identify what factors might, or might not be useful in explaining a pattern. Similarly, definitions of widely used terms change as their uses change, and make their way through the literature. Resilience, like 'connectivity', is an excellent example of this. Connectivity depends on what species is/are

${ }^{1}$ This is an overestimate due to the fact that the Pimm (1991) citations refer to the entire book. Removing this reference leaves a total of 2590 references. 
being considered (Tischendorf and Fahrig 2003), and similarly resilience can be applied to the entire planet (Steffen et al. 2011), biomes and ecosystems (Chapin et al. 2004, Johnstone et al. 2010), communities (Brock et al. 2003, Rydgren et al 2004), species (Stork et al. 2009), populations (Kerr et al. 2010), and even socialecological systems (Berkes et al. 1998).

Scientific research proceeds by formulating hypotheses about how nature might work, testing those hypotheses by gathering data, then rejecting the hypotheses that don't agree with the observations (e.g., Hilborn and Mangel 1997). In many cases multiple working hypotheses are formulated, with these hypotheses being relatively similar: rejection of any of the hypotheses through observation leaves refined ideas about nature. Similarly, in ecology we have a habit of developing new terminology to explain patterns, often well before we have determined what processes lead to those patterns. These terms get refined over time, becoming more useful in the process. Defining them rigidly at their introduction would prohibit them from being treated as something like hypotheses to be tested and refined. Rigidity and science are strange bedfellows.

What do we do with resilience? It is worth returning to Holling's original definition of the term (Holling 1973:17): "Resilience determines the persistence of relationships within a system and is a measure of the ability of these systems to absorb changes of state variables, driving variables, and parameters, and still persist." Effectively, this term might be viewed as part of the ushering in of the modern study of the environment: despite the use of the word 'persistence', this is a non-equilibrium definition that moves beyond keeping individual components (i.e., species) in a system, and instead focuses on the important processes that maintain ecosystem services. Resilience has been very important in our understanding of:

- Linked social-ecological systems (e.g., Berkes et al. 1998).

- Responses at multiple scales (e.g., Cumming 2011)

- Management of large-scale ecosystems (e.g., Chapin et al. 2009)

It has been stated before that terminology that does not include a mathematically-derived definition is very difficult to be specific about (Starzomski et al. 2004). When mathematically stated, that term can be used very specifically. This can't always happen, however, and many ill-defined terms in ecology have stimulated massive bodies of important research (e.g., connectivity, habitat, niche). In fact, because of the complexity of ecological systems, very specific and narrow definitions are rare. While calling for increased rigor in the definition of all terms is a good idea, for a term like resilience it is probably impossible and might stunt the growth of studies that have provided important guidance for contemporary environmental management structures. Best that these discussions take place in the peerreviewed literature (as Myers-Smith et al. (2012) have done) given the role resilience has assumed in our management structures (Holling and Meffe 1996). Nevertheless, being clear about exactly what components of resilience are being examined (e.g., return time, population size, etc.), for what structures (e.g., genes, species, ecosystems, etc.), and for what space and time scales, is absolutely essential, as Myers-Smith et al. (2012) rightly point out. To the extent that terminology is useful when it promotes deep discussion within a field, I believe the development and use of 'resilience' have been massively successful and important in ecology, and remain optimistic about the term's continuing utility to our science and the application of its discoveries.

\section{References}

Berkes, F., and C. Folke, editors. 1998. Linking Social and Ecological Systems: Management Practices and Social Mechanisms for Building Resilience. Cambridge University Press, Cambridge.

Brock, M.A., Nielsen, D.L. Shiel, R.J., Green, J.D. and J.D. Langley. 2003. Drought and aquatic community resilience: the role of eggs and seeds in sediments of temporary wetlands. Freshwater Biology 48:12071218. CrossRef

Carpenter, S.R., Kraft, C.E., Wright, R., He, X., Soranno, P.A. and J.R. Hodgson. 1992. Resilience and resistance of a lake phosphorus cycle before and after food web manipulation. American Naturalist 140:781-98. CrossRef

Carpenter, S.R., Walker, B., Anderies, J.M. and N. Abel. 2001. From metaphor to measurement: resilience of what to what? Ecosystems 4:765-81. CrossRef

Chapin, F.S., Hoel, M., Carpenter, S.R., Lubchenco, J., Walker, B., Callaghan, T.V., et al. 2006. Building resilience and adaptation to manage arctic change. AMBIO: A Journal of the Human Environment 35: 198-202.

Chapin, F.S., Kofinas, G.P., and C. Folke, editors. 2009. Principles of Ecosystem Stewardship: ResilienceBased Natural Resource Management in a Changing World. Springer, New York.

Cumming, G.S. 2011. Spatial Resilience in Social-Ecological Systems. Springer, London. CrossRef

Gunderson, L. 2000. Ecological resilience-in theory and application. Annual Review of Ecology and Systematics 31:425-439. CrossRef

Hilborn, R., and M. Mangel. 1997. The Ecological Detective: Confronting Models with Data. Princeton University Press, New Jersey. 
Hodges, K.E. 2008. Defining the problem: terminology and progress in ecology. Frontiers in Ecology and the Environment 6:35-42. CrossRef

Holling, C.S. 1973. Resilience and stability of ecological systems. Annual Review of Ecology and Systematics 4:1-23. CrossRef

Holling, C.S. 1996. Engineering resilience vs. ecological resilience. Pages 31-44 in P.C. Schulze, editor. Engineering within ecological constraints. National Academy Press, Washington, D.C.,USA.

Holling, C., and G. Meffe. 1996. Command and control and the pathology of natural resource management. Conservation Biology 10:328-337. CrossRef

Johnstone, J.F., Chapin, F.S., Hollingsworth, T.N., Mack, M.C., Romanovsky, V., and M. Turetsky. 2010. Fire, climate change, and forest resilience in interior Alaska. Canadian Journal of Forest Research 40:1302-1312. CrossRef

Mikkelson, G.M. 1997. Methods and metaphors in community ecology: the problem of defining stability. Perspectives on Science 5: 481-498.

Myers-Smith, I. H., Trefry, S.A., and V.J. Swarbrick. 2012. Resilience: easy to use but hard to define. Ideas in Ecology and Evolution 5:44-53. CrossRef

Pimm, S.L. 1991. The Balance of Nature? Ecological Issues in the Conservation of Species and Communities. University of Chicago Press, Chicago, USA.

Resilience Alliance and Santa Fe Institute. 2012. Thresholds and alternate states in ecological and social-ecological systems. Resilience Alliance. (Online) URL: http://www.resalliance.org.
Rydgren, K., Økland, R.H., and G. Hestmark. 2004. Disturbance severity and community resilience in a Boreal forest. Ecology 85:1906-1915. CrossRef

Shrader-Frechette, K.S., and E.D. McCoy. 1993. Method in Ecology: Strategies for Conservation. Cambridge University Press, Cambridge, UK. CrossRef

Starzomski, B.M., Cardinale, B.J., Dunne, J.A., Hillery, M.J., Holt, C.A., Krawchuk, M.A., et al. 2004. Contemporary visions of progress in ecology and thoughts for the future. Ecology and Society 9:14.

Steffen, W., Persson, A., Deutsch, L., Zalasiewicz, J., Williams, M., Richardson, K., et al. 2011. The Anthropocene: From global change to planetary stewardship. AMBIO: A Journal of the Human Environment 40:739-761.

Stork, N.E., Coddington, J.A., Colwell, R.K., Chazdon, R.L., Dick, C.W., Peres, C.A., et al. 2009. Vulnerability and resilience of tropical forest species to land-use change. Conservation Biology 23:14381447. CrossRef

Tischendorf L. and L. Fahrig. 2000. On the usage and measurement of landscape connectivity. Oikos 90:719. CrossRef

Vellend, M. 2010. Conceptual synthesis in community ecology. The Quarterly Review of Biology 85:183206. $\underline{\text { CrossRef }}$

Walker, B., Holling, C.S., Carpenter, S. and A. Kinzig. 2004. Resilience, adaptability and transformability in social-ecological systems. Ecology and Society 9:5. 